\title{
New family with HSPB8-associated autosomal dominant rimmed vacuolar myopathy
}

Sejad Al-Tahan, DO, * Lan Weiss, MD, PhD, * Howard Yu, BS, Sha Tang, PhD, Mario Saporta, MD, PhD, Anna Vihola, PhD, Tahseen Mozaffar, MD, Bjarne Udd, MD, PhD, and Virginia Kimonis, MD

Neurol Genet 2019;5:e349. doi:10.1212/NXG.0000000000000349
Correspondence

Dr. Kimonis

vkimonis@uci.edu

\section{Abstract}

\section{Objective}

We clinically and molecularly characterize a new family with autosomal dominant rimmed vacuolar myopathy (RVM) caused by mutations in the HSPB8 gene.

\section{Methods}

We performed whole-exome and whole-genome sequencing in the family. Western blot and immunocytochemistry were used to analyze 3 patient fibroblasts, and findings were compared with their age- and sex-matched controls.

\section{Results}

Affected patients have distal and proximal myopathy, with muscle biopsy showing rimmed vacuoles, muscle fiber atrophy, and endomysial fibrosis typical of RVM. Muscle MRI showed severe relatively symmetric multifocal fatty degenerative changes of the lower extremities. We identified a duplication of $\mathrm{C}$ at position 515 of the HSPB8 gene (c.515dupC) by whole-genome sequencing, which caused a frameshift with a predicted alternate stop codon p.P173SFS* 43 in all affected individuals, resulting in an elongated protein product. Western blot and immunocytochemistry studies revealed reduced expression of heat shock protein beta 8 in patient fibroblasts compared with control fibroblasts, in addition to disrupted autophagy pathology.

\section{Conclusions}

We report a novel family with autosomal dominant RVM caused by the c.515dupC mutation of the HSPB8 gene, causing a translational frameshift that results in an elongated protein. Understanding the mechanism for the RVM pathology caused by mutated chaperone will permit novel targeted strategies to alter the natural history progression. As next-generation sequencing becomes more available, additional myopathic families will be identified with HSPB8 mutations.

\footnotetext{
*These individuals are co-first authors.
}

From the Division of Genetics and Genomic Medicine (S.A.-T., L.W., H.Y.), Department of Pediatrics, University of California, Irvine; Opti West (S.A.-T.), West Anaheim Medical Center, Anaheim; Ambry Genetics (S.T.), Mission Viejo, CA; Miller School of Medicine (M.S.), University of Miami, FL; Folkhälsan Institute of Genetics and the Department of Medical Genetics (A.V., B.U.), Medicum, University of Helsinki; Neuromuscular Research Center (A.V., B.U.), Tampere University and University Hospital, Neurology, Finland; Neuromuscular Program (T.M.), Department of Neurology, University of California-Irvine, Orange; and Neurology Department (B.U.), Vasa Central Hospital, Finland. 


\section{Glossary}

CASA = chaperone-assisted selective autophagy; CMT = Charcot-Marie-Tooth; FLNC $=$ filamin C; HSPB $=$ heat shock protein beta; MRI = Medical Research Council; NCS = nerve conduction study; RVM = rimmed vacuolar myopathy.

Heat shock protein beta 8 (HSPB8), also known as heat shock protein 22 , is involved in chaperone-assisted selective autophagy (CASA) in cells. ${ }^{1}$ CASA is a process that maintains muscle cytoskeleton by facilitating the degradation of damaged components. Disruption of genes in the chaperone-assisted degradation pathway is implicated in several myopathies. CASA interacts with filamin C (FLNC), a flexible actin cross-linker that is present within muscle $\mathrm{Z}$-disks ${ }^{2}$ and along cytoskeletonassociated integrin where it functions to anchor actin during mechanical stress. ${ }^{3}$ DnaJ Heat Shock Protein Family (Hsp40) Member B6 (DNAJB6) thought to be the first protein that interacts with Heat Shock Protein Family A (Hsp70) Member 8 $(\mathrm{HSPA} 8)^{4}$ then complexes with HSPB8. BCL2 Associated Athanogene 3 (BAG3) is a coupling factor that mediates HSPA8 and HSPB8 interaction. ${ }^{1}$ Mutations of several CASA-associated proteins are known to be associated with myopathies: DNAJB6 is associated with limb-girdle muscular dystrophy $1 \mathrm{D},{ }^{5} \mathrm{BAG} 3{ }^{6,7}$ and FLNC with skeletal and cardiac myopathies. ${ }^{8,9}$

Previous studies associated HSPB8 mutations with CharcotMarie-Tooth (CMT) type $2 \mathrm{~L}^{10,11}$ and distal hereditary motor neuropathy type IIa. ${ }^{12}$ It was only after an exome analysis that the association with distal myofibrillar and rimmed vacuolar neuromyopathy was established, ${ }^{13}$ identifying a heterozygous change in HSPB8 in 2 families: c.421A $>$ G; p.K141E in family 1 and the c.515 insC p.P173SfsX43 in family 2. Affected patients had a distal neuromyopathy that showed myofibrillar aggregates and rimmed vacuoles combined with a clear neurogenic component on biopsy and EMG studies. Recently, a c.508_509delCA mutation was identified, predicted to produce a frameshift mutation leading to alteration of the last 27 amino acids and elongation of the polypeptide by 17 residues in 3 families. ${ }^{14}$ Finally, a family was identified with c.421A $>$ G p.K141E HSPB8 mutations manifesting with pes cavus, hammer toes, and muscle atrophy with biopsy findings including rimmed vacuoles and myopathic changes. ${ }^{15}$ Here, we describe a new family with an HSPB8 p.Pro173fs mutation manifesting as rimmed vacuolar myopathy (RVM).

\section{Methods}

\section{Standard protocol approvals, registrations, and patient consents}

This study was approved by the University of California Irvine Institutional Review Board (\#2009-1005). All subjects provided approved consent for the studies. The study is also listed in ClinicalTrials.gov (Identifier: NCT01353430).

\section{Molecular studies}

Extensive gene panel of the genes involved in neuromuscular diseases performed by EGL Genetics Diagnostic Laboratory at Emory University was negative for the following 35 genes: AN05, CAPN3, CAV3, COL6A1, COL6A2, COL6A3, DAG1, DES, DMD, DYSF, EMO, FHL1, FKRP, FKTN, FLNC, GAA, GNE, ISPD, LMNA, MYOT, PLEC, POMGNT1, POMT1, POMT2, SGCA, SGCB, SGCD, SGCG, SMCHD1, SYNE1, SYNE2, TCAP, TRIM32, TTN, and VCP.

Whole-exome sequencing and segregation analysis was performed by Ambry Genetics. ${ }^{16}$ Briefly, the sample was prepared using the IDT xGen Exome Research Panel V1.0 (Integrated DNA Technologies), sequenced using the Illumina HiSeq4000 sequencer (Illumina, San Diego, CA). Data processing and interpretation were performed as previously described. ${ }^{16}$

Subsequent genome sequencing was performed by Otogenetics Corporation (Atlanta, GA) and the data analyzed by Variantyx, Inc. (Framingham, MA). For sequencing, libraries were generated using the Truseq Nano DNA Library Sample preparation Kit and sequenced on the Illumina HiSeq X Ten system (Illumina, USA) to achieve average read depth of about 30X. Variants were detected, annotated, analyzed, and reported using the Genomic Intelligence platform (version 1/ .13.2.0) integrating the knowledge in a variety of databases and tools (Variantyx Inc). Sanger sequencing was used to confirm the HSPB8 variant in the proband and for segregation studies in his family.

\section{HSPB8 protein study and autophagic activity of mutant HSPB8}

Because of the unavailability of patient myoblasts, we studied patient fibroblasts from the proband, his mother, and maternal uncle derived from skin biopsy samples (P1: 64-001, P2: 64-002, P3: 64-005). Fibroblasts of the 3 age- and sexmatched healthy controls from Coriell Repository ( $\mathrm{C} 1$ : GM22246, C2: AG12786, C3: AM03529A) were used to test the HSPB8 expression level for comparison. Western blotting and immunocytochemistry studies using HSPB8 antibody (Millipore Sigma HPA015876) were performed as previously described. ${ }^{17}$ We also monitored the autophagic activity of mutant $\mathrm{HSPB}^{18}$ using autophagosomal markers LC3B (Abcam, ab48394), P62/SQSTM1 (ab56416), and BAG3 (ab47124) antibodies.

\section{HSPB8 protein expression under heat shock conditions}

Under stress conditions such as heat shock, the concentration of small heat shock proteins such as HSPB8 would be expected to increase to perform their chaperone activity of binding to misfolded proteins and blocking the formation of aggregates. ${ }^{19,20}$ The heat shock experiment was performed as 
follows: fibroblasts were seeded on chambered slides (Ibidi, IbiTreat 80826) in subconfluent density for 24 hours. The slides were sealed with parafilm, placed in an aluminum foil box, and immersed in $43^{\circ} \mathrm{C}$ water bath for 30 minutes. Unheated control slides were also sealed for 30 minutes but kept in an incubator $\left(37^{\circ} \mathrm{C}\right)$. Then, all slides were unsealed, and their recovery was followed for 24 hours in the incubator before immunocytochemistry was performed. ${ }^{19,20}$

\section{Data availability}

All the data from this study will be made available.

\section{Results}

\section{Clinical studies}

\section{Case 1}

The proband (IV:8) is a 44-year-old man born to nonconsanguineous Northern European parents of French ancestry with a family history of autosomal dominant inheritance of muscle weakness in his mother and his maternal uncle (figure 1). He was an all-state athlete in his 20 s. He had persistent elevated liver enzymes from age 28 years and first noticed lower limb weakness in the mid-30s with progressive bilateral foot drop and occasional falls. At age 35 years, he developed foot pain and ankle dorsiflexion weakness for which he wore ankle foot orthoses. At age 42 years, he noticed difficulty raising his arms above his head, and at age 43 years, difficulty rising from a chair and climbing stairs.

On physical examination, there was mild scapular winging (figure 2), diffuse muscle weakness noted predominantly in the lower extremities, and no sensory loss. He had a wide steppage gait related to his bilateral foot drop, was unable to tandem walk or walk on his heels or toes, and had a lumbar lordosis. The Medical Research Council (MRC) scale score of his foot dorsiflexors was $2 / 5$, and that of the extensor hallucis longus was $1 / 5$ on the right and $2 / 5$ on the left. The MRC scale score of the infraspinatus, deltoid, finger extensors, hip flexors, hip extensors, knee flexors, hip adductors, and hip abductors was $4 / 5$. Reflexes were diminished $1 / 4$ bilaterally of the biceps, triceps, brachioradialis, knee, and absent at the ankle. T1-weighted MRI showed severe relatively symmetric multifocal fatty degenerative changes of the lower extremities, preferentially affecting the vastus medialis and intermedius, adductor magnus and semitendinosus at the thigh level, and predominantly anterior and lateral compartments more than calf muscle of the lower legs (figure 2, B and C). Laboratory studies revealed normal comprehensive metabolic profile, normal alkaline phosphatase $28 \mathrm{U} / \mathrm{L}$, and elevated total cholesterol $237 \mathrm{mg} / \mathrm{dL}$ (normal < $150 \mathrm{mg} / \mathrm{dL}$ ). His medical history included asymptomatic right bundle branch block, pseudogout, benign prostatic hyperplasia, and rosacea. Although he was asymptomatic, pulmonary function studies revealed respiratory insufficiency with decreased Forced Vital Capacity (sitting) of $4 \mathrm{~L}$ ( $43 \%$ of predicted). His maximum inspiratory pressure was $-72 \mathrm{~cm} \mathrm{H}_{2} \mathrm{O}$. BiPAP was recommended for his respiratory insufficiency. The patient is taking nonprescribed nutritional supplements.

\section{Case 2}

The proband's mother (III:14) aged 64 years first presented with difficulty raising her arms and weakness in her legs and feet not until age 56 years. She then progressed to having difficulty walking up stairs at age 59 years and developed difficulty walking on flat ground and weakness in her hands at age 60 years. Her medical history included hyperuricemia, hypertension, and type 2 diabetes mellitus and tendon surgery of her right thumb.

Figure 1 Family pedigree showing autosomal dominant inheritance

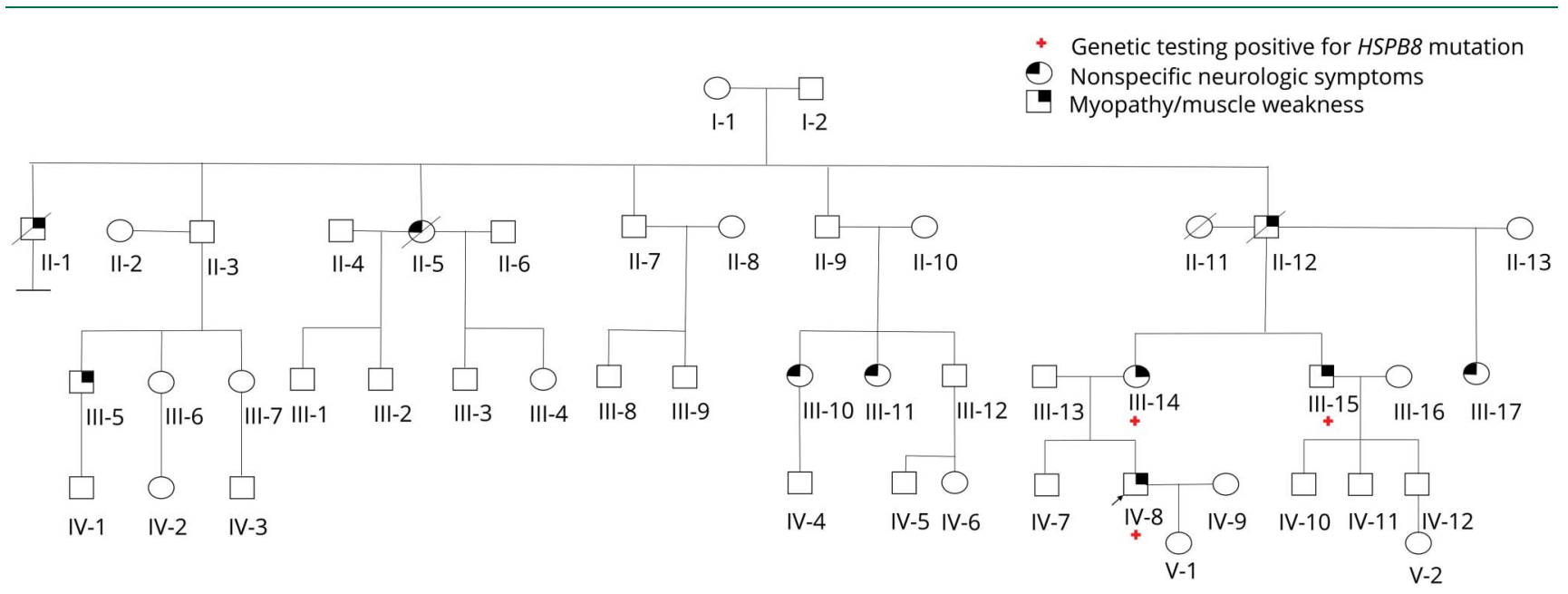

The filled upper right quadrant indicates myopathy, and the filled upper left quadrant indicates nonspecific neurologic symptoms. The arrow indicates the proband. 
Figure 2 Muscular involvement of the HSPB8 disease
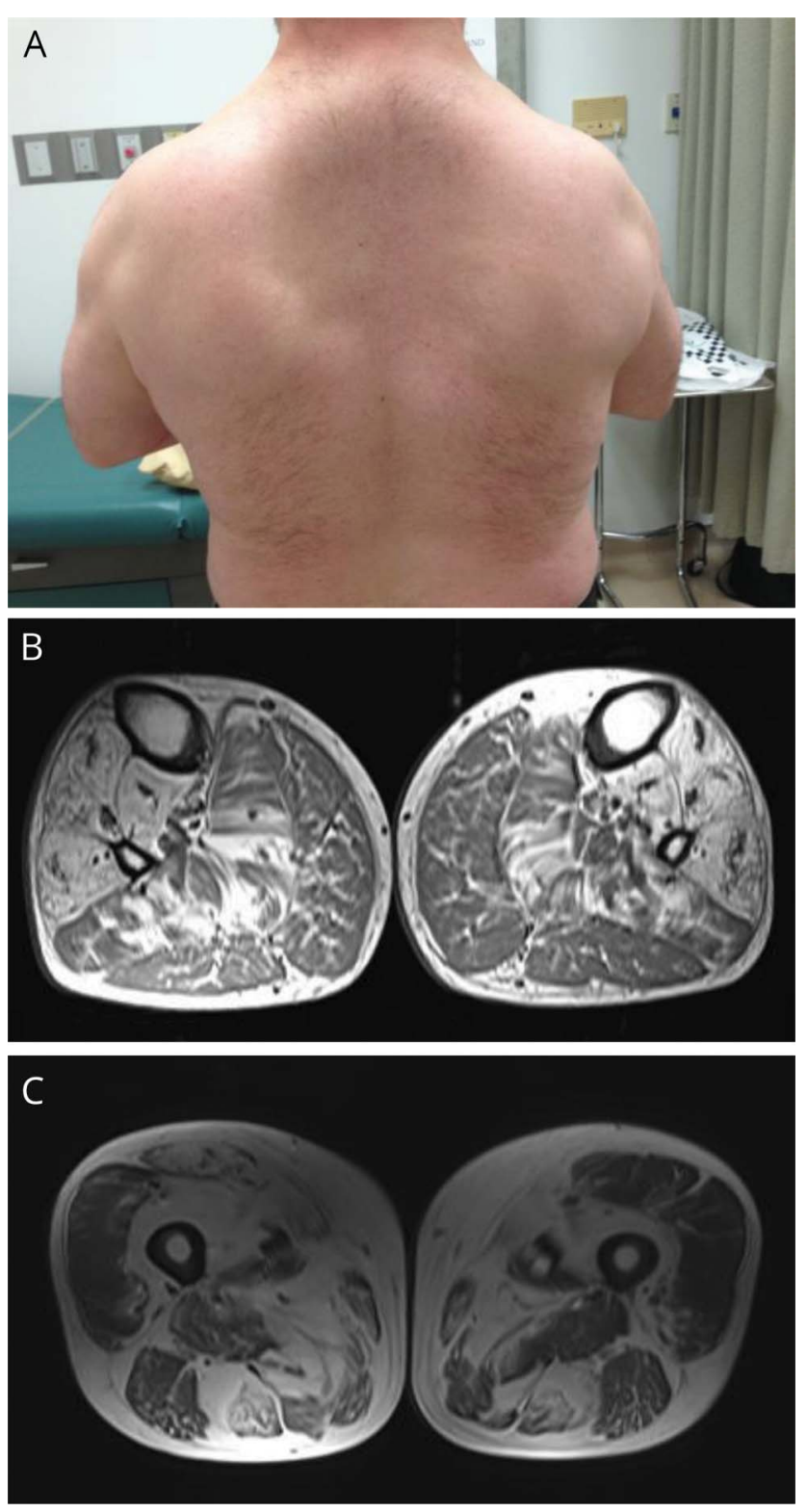

(A) Photograph of the proband showing scapular winging and bilateral wasting of deltoids. (B) T1-weighted MRI of the proband showing severe relatively symmetric multifocal fatty degenerative changes of bilateral lower extremities and (C) proximal lower extremities preferentially affecting the vastus medialis and intermedius together with the adductor magnus and semitendinosus on the thigh level, as well as predominately anterior and lateral compartments more than soleus muscle of the distal legs.

Physical examination revealed mild distal extremity weakness and diminished 1/4 reflexes bilaterally of her biceps, triceps, brachioradialis, and patella. Her Achilles tendon reflex was absent. She had a wide based and unbalanced gait with a lordotic posture. There was no scapular winging, pes cavus, skeletal dysplasia, respiratory distress, signs of cranial nerve involvement, or sensory loss. CT of the lung revealed right basilar consolidative infiltrate vs atelectasis at the left lung base.

Muscle biopsy of her left vastus lateralis revealed adipose tissue infiltration, moderate to severe endomysial fibrosis, muscle fiber size variation, numerous atrophic muscle fibers, increase of internalized nuclei, and rimmed vacuoles. There were no necrotic fibers, regenerating muscle fibers, or evidence of inflammation (figure 3 ). No medications were prescribed for this patient.

\section{Case 3}

The proband's maternal uncle (III:15) is a 66-year-old man who first became aware of a steppage gait at 42 years and weakness of his great toe and right hand at age 44 years. This progressed to using a cane and difficulty going up stairs at age 46-47 years. At age 52 years, he started swimming instead of running for exercise and starting to use Canadian crutches. At age 59 years, he started using a manual wheelchair, and at age 64 years, he transitioned to a power wheelchair. At age 61 years, he has noticed that his breathing became more difficult.

His medical history includes neurogenic bladder, mild obstructive sleep apnea, gout and hearing loss of his right ear, and 20 incidences of recurrences of basal cell nevi and squamous cell carcinoma of the skin.

On physical examination, there was no pes cavus, skeletal dysplasia, camptocormia, scapular winging, or signs of cranial nerve or cerebellar involvement. He had reduced sensation to light touch below knees bilaterally, and muscle strength examination revealed distal $>$ proximal weakness. The MRC scales were neck flexion $4-/ 5$, neck extension $4 / 5$, shoulder abduction $4-/ 5$, elbow flexion $4-/ 5$ and extension $3+/ 5$, finger abduction $5-/ 5$, hip flexion $2 / 5$ and extension $3+/ 5$, knee flexion $3+/ 5$ and extension $2 / 5$, ankle dorsiflexion $1 / 5$, and plantarflexion $3-/ 5$. EMG and nerve conduction studies (NCSs) revealed abnormal findings suggestive of a myopathic pattern primarily in distal musculature with evidence of a motor neuropathy.

Chest x-ray revealed low lung volumes without evidence of cardiovascular disease. Pulmonary function tests revealed restrictive lung disease with poor lung capacity with a forced vital capacity of $43 \%$, and BiPAP was recommended. Cardiac CT showed an elevated coronary calcium score of 244 but no cardiomyopathy.

Body CT revealed atrophy and fatty infiltration of his psoas muscle, benign prostatic hyperplasia, atelectasis with prominent interstitial markings of his lung bases bilaterally, renal cyst, gallstone, and a calcified granuloma in his liver. No medications were prescribed for this patient.

\section{Family history of other relatives}

Family history was significant for the proband's maternal grandfather losing his ability to walk at age 38 years and for developing cardiac problems in his fifties. On review of the extended family, his grandfather's brother lost his ability to walk at age 35 years, and the great grandmother lost her ability to walk at age 56 years. Five other family members reported nonspecific neurologic symptoms; however, these individuals tested negative for the familial mutation. Figure 4 depicts the pedigree with HSPB8 mutation status indicated with a "+." 


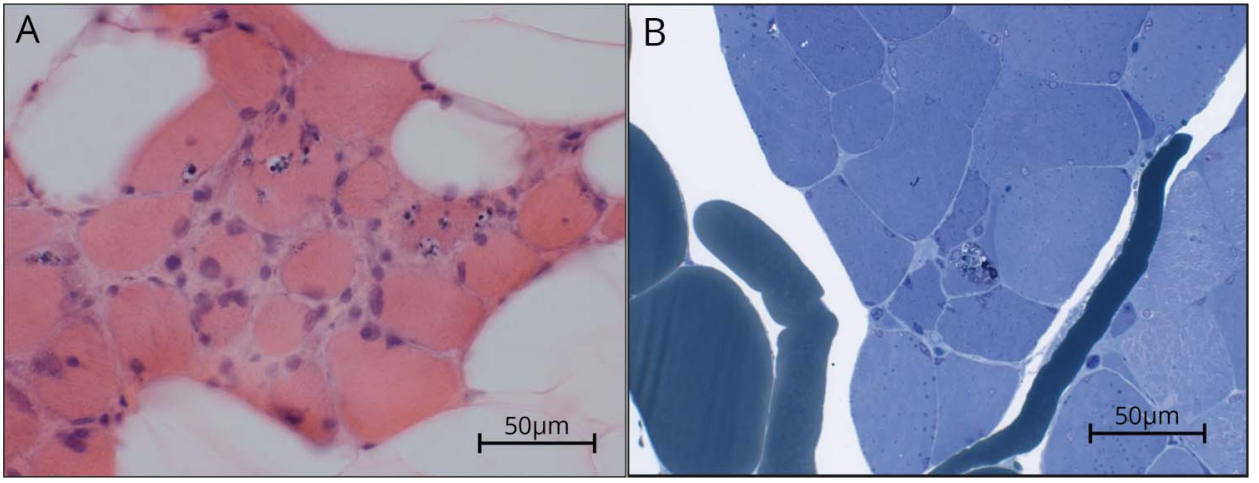

(A) Muscle histology of a biopsy of the left vastus lateralis from case 2 shows the presence of rimmed vacuoles (in 3 fibers), adipose replacement, moderate to severe endomysial fibrosis, muscle fiber size variation, numerous atrophic muscle fibers, and increase in central nuclei. (B) Semithin section stained with toluidine blue showing a single fiber with accumulated autophagic vacuoles, corresponding to rimmed vacuolar changes in muscle cryosections.

\section{Molecular studies}

Extensive neuromuscular 35-gene panel testing was negative in the proband and uncle notably for facioscapulohumeral muscular dystrophy, GNE and VCP associated hereditary inclusion body myopathy. Full exome sequencing and genotype-phenotype correlation based on exome data analysis revealed notable alterations in CCDC78, HSPB8, MUSK, MYH14, TRIM32, and TTN-none of which was

Figure 4 Sequencing of the $H S P B 8$ gene

A

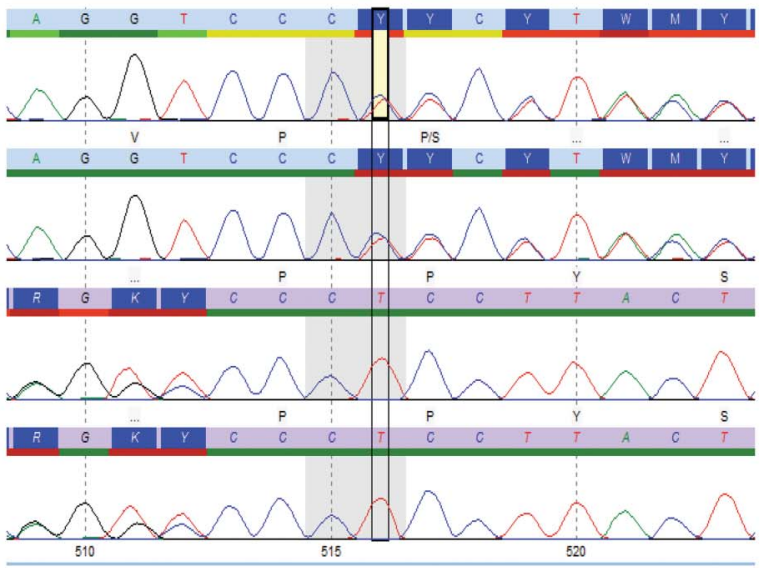

C

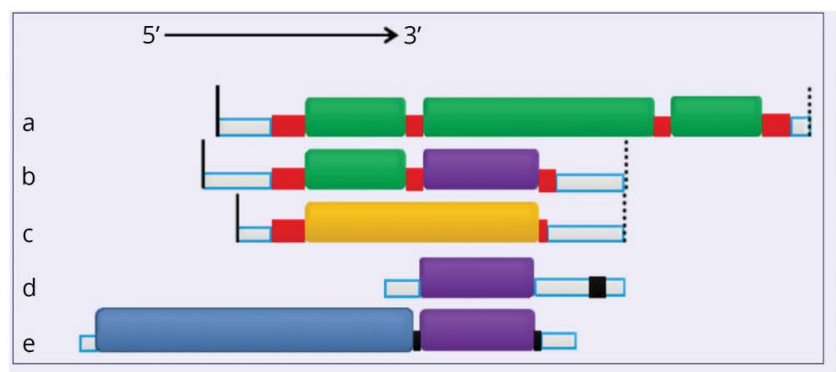

B. Nucleotide alignment

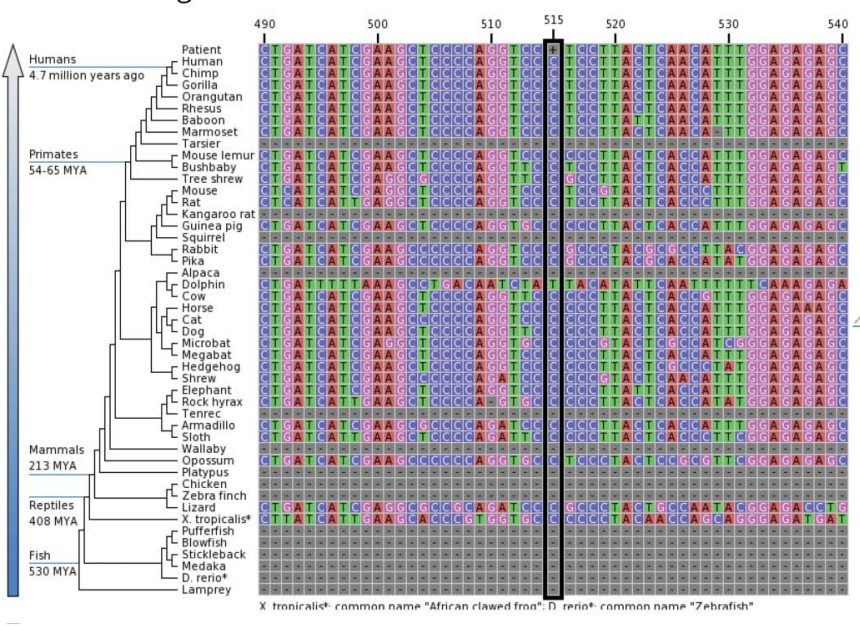

D. Protein

Reference

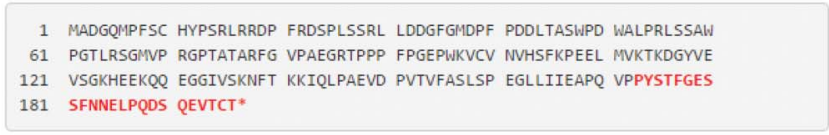

Predicted from variant coding sequence

1 MADGOMPFSC HYPSRLRRDP FRDSPLSSRL LDDGFGMDPF PDDLTASWPD WALPRLSSAW

61 PGTLRSGMVP RGPTATARFG VPAEGRTPPP FPGEPWKVCV NVHSFKPEEL MVKTKDGWE

121 VSGKHEEKQQ EGGIVSKNFT KKIQLPAEVD PVTVFASLSP EGLLIIEAPQ VPSLLNIWRE 181 QFQQRASPGQ PGSHLYLRCQ MWPILVLSPT LGLL*

(A) Chromatogram from the proband revealing the frameshift mutation c.515dupC p.Pro173fs, which was similarly identified in all affected individuals. (B) The mRNA that results from this mutation has 5 splice variants with size ranging from 27 to 244 aa. Only the first 3 contain an a-crystallin domain and are coding. The red boxes are exons with their size being proportional to their length. The wide colored boxes are introns. Similarly colored introns are identical. The purple introns are upstream open reading frames. The solid black vertical lines indicate validated cap sites at the $5^{\prime}$ end, and the dotted black lines indicate validated polyadenylation sites at the $3^{\prime}$ end. The clear boxes are untranslated regions. (C) Conservation of the sequence of amino acids within HSPB8 across species reveals a very well conserved protein. (D) The predicted sequence of amino acids in the mutant HSPB8 protein (214 amino acids) is longer than its wild-type counterpart (196 amino acids). 
considered contributory based on the known molecular and clinical spectrum of these genes at the time of testing. Subsequent genome sequencing identified a mutation in the HSPB8 gene identical to the French family 2, which had recently been reported by Ghaoui et al. ${ }^{13}$ after whole-exome analysis.

\section{HSPB8 p.Pro173fs}

The HSPB8 gene mutation identified consists of a duplication of $\mathrm{C}$ at position 515, located in coding exon 3 (the last coding exon) causing a translational frameshift with a predicted alternate stop codon (c.515dupC, p.P173Sfs*43). The alteration changes the remaining 25 amino acids of the protein and elongates the protein by a further 18 amino acids (figure 4). This variant is not observed in any of the control population databases including gnomAD. The calculated severity score is 1.0 on a scale of $0.0-1.0$. According to Human Gene Mutation Database/ClinVar, the HSPB8 gene is associated with CMT disease 2L; neuropathy, distal hereditary motor, type II; distal myopathy and motor neuropathy; and distal hereditary motor neuronopathy type 2 . Recently, the 515 dupC, p.P173Sfs $* 43$ variant had been associated with a progressive distal myopathy and neuropathy in a proband and his brother. Muscle tissue in the proband showed increased internal nuclei, numerous rimmed vacuolar fibers, splitting, cytoplasmic bodies, and moth-eaten fibers. ${ }^{13}$

\section{HSPB8 and autophagy protein expression in mutant HSPB8 fibroblasts}

Western blot densitometry exhibited up to $50 \%$ reduction of HSPB8 protein expression level in fibroblasts from patients with the HSPB8 mutation c.515dupC, p.P173SFS*43 mutation compared with control fibroblasts (figure 5, A and B). The expression of autophagosomal marker LC3B and autophagy receptor p62/ SQSTM1 was more pronounced in all patients' fibroblasts in comparison to those from healthy subjects (figure 5).

\section{HSPB8 protein expression under heat shock conditions}

As expected, heat shock led to a significant induction of HSPB8; however, following the recovery phase, an excessive amount of HSPB8 protein aggregates was still present in all 3 heated fibroblasts from patients compared with the unheated ones. This phenomenon was not seen in healthy control cells (figure 6).

Figure 5 Expression of HSPB8, LC3B, p62/SQSTM1, and BAG3 proteins comparison in patients versus controls

A

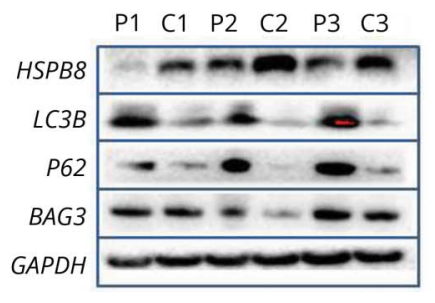

C

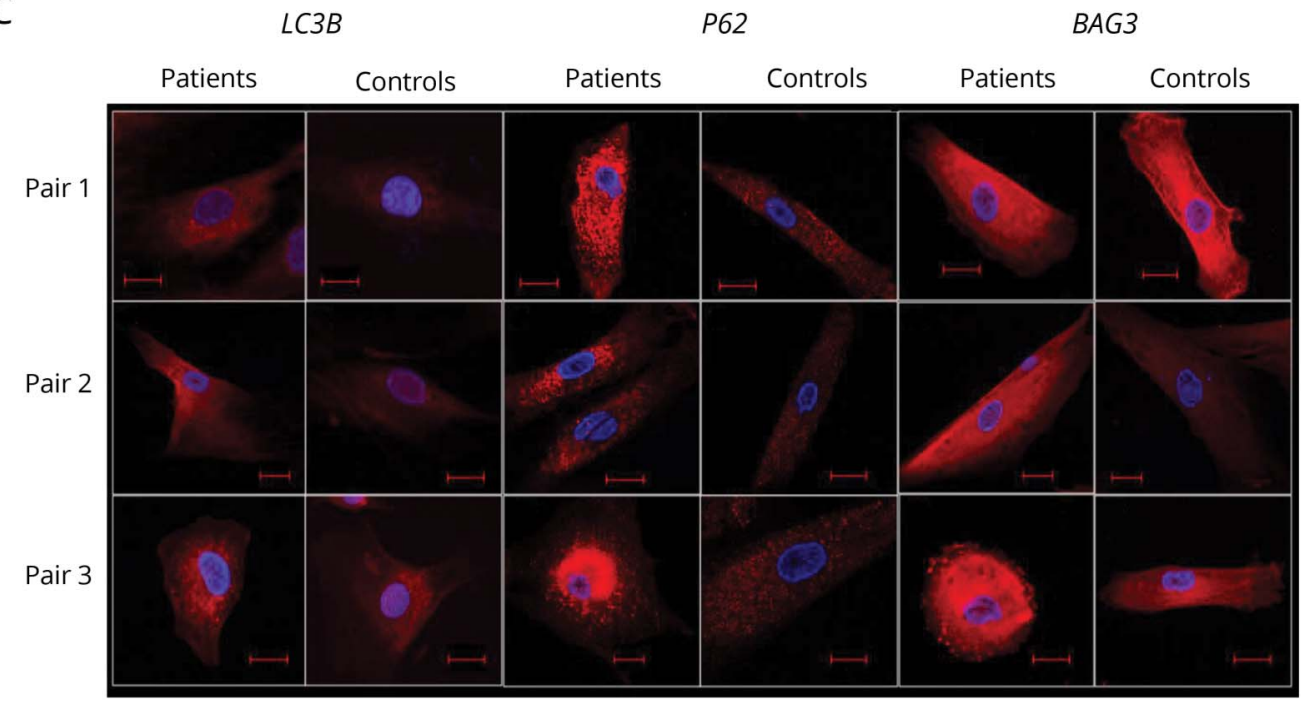

(A) Western blot revealed low HSPB8, increased autophagy (LC3, p62) protein expression in patient fibroblasts compared with age- and sex-matched controls. GAPDH was used as a positive loading control. (B) Densitometry analyses of the Western blot results (C) Immunocytochemistry images by confocal microcopy confirmed Western blotting data. Pair 1: patient (P1) and control (C1) fibroblasts; pair 2: P2 and C2; pair 3: P3 and C3. 


\section{Discussion}

HSPB8 is part of the chaperone-assisted selective autophagy (CASA) complex previously associated with CMT type $2 \mathrm{~L}^{10,11}$ and distal hereditary motor neuropathy type IIa. ${ }^{12}$ Only recently has the new association of hereditary rimmed vacuolar neuromyopathy been described with mutations in the HSPB8 gene. ${ }^{13-15}$ We report 3 patients from a new family with histologic features of myofibrillar myopathy with aggregates and rimmed vacuoles. The onset of the disease is very similar to the other reported families ${ }^{13-15}$ and manifests as a myopathy before age 50 years affecting the lower extremities more commonly than the upper extremities. The MRI distribution of muscle involvement in our cohort includes muscles of the distal lower extremities similar to previous studies ${ }^{13}$ that described T1-weighed MRI findings of the lower limb muscles and demonstrated diffuse tissue changes early in the disease stage progressing later to fatty replacement typical of a myopathy. In addition, there was a previous report of 5 cases from 2 families and a sporadic case, all with the same HSPB8 c.508_509delCA (p.Gln170Glyfs*45) mutation predicted to induce a frameshift from amino acid 170 leading to modification of the last 27 amino acids and to 17 additional amino acids. ${ }^{14}$ Individuals had bilateral foot drop starting at age 40 years, histology of muscle demonstrated a dystrophic and myofibrillar myopathy pattern, and MRI showed fatty changes in several muscles including paraspinal muscles and lower limb muscles including the vastus muscles, tibialis anterior, and extensor digitorum longus similar to those reported previously ${ }^{13}$ (table). Most recently, triplets and their mother were reported with distal and proximal muscle weakness, EMG showed mixed myopathic and neurogenic changes, and NCSs showed findings of an axonal neuropathy. ${ }^{15}$ Muscle biopsy findings were that of a primary myopathy with rimmed vacuoles in $20 \%$ of patients, and MRI revealed fatty degeneration mostly in the quadriceps, adductor magnus, medial gastrocnemius, and peroneus muscles (table).

The family of small heat shock proteins (HSPBs1-10) (22 $\mathrm{kDa}$ ) represents an important group of ubiquitous proteins involved in several key processes of cellular physiology, such as cell survival, cytoskeletal remodeling, and protein degradation. Aberrant chaperone function is the likely mechanisms for the pathologic protein aggregation seen in HSPB8 disease. The HSPB8 c.K141E mutation associated with CMT impairs chaperone activity, ${ }^{21}$ which suggests that the defective or decreased activity is associated with the deteriorating motor neuron function. HSPB8 expression within motor neurons declines with age, ${ }^{20}$ which has been hypothesized as the mechanism of the disease presenting in older ages and progressing with age. ${ }^{18} \mathrm{~A}$ contributing factor to the susceptibility of these patients may be impaired formation of neurites in HSPB8 mutants. ${ }^{22}$ The HSPB8 pathology is similar to the

Figure 6 Expression of HSPB8 protein under heat shock condition

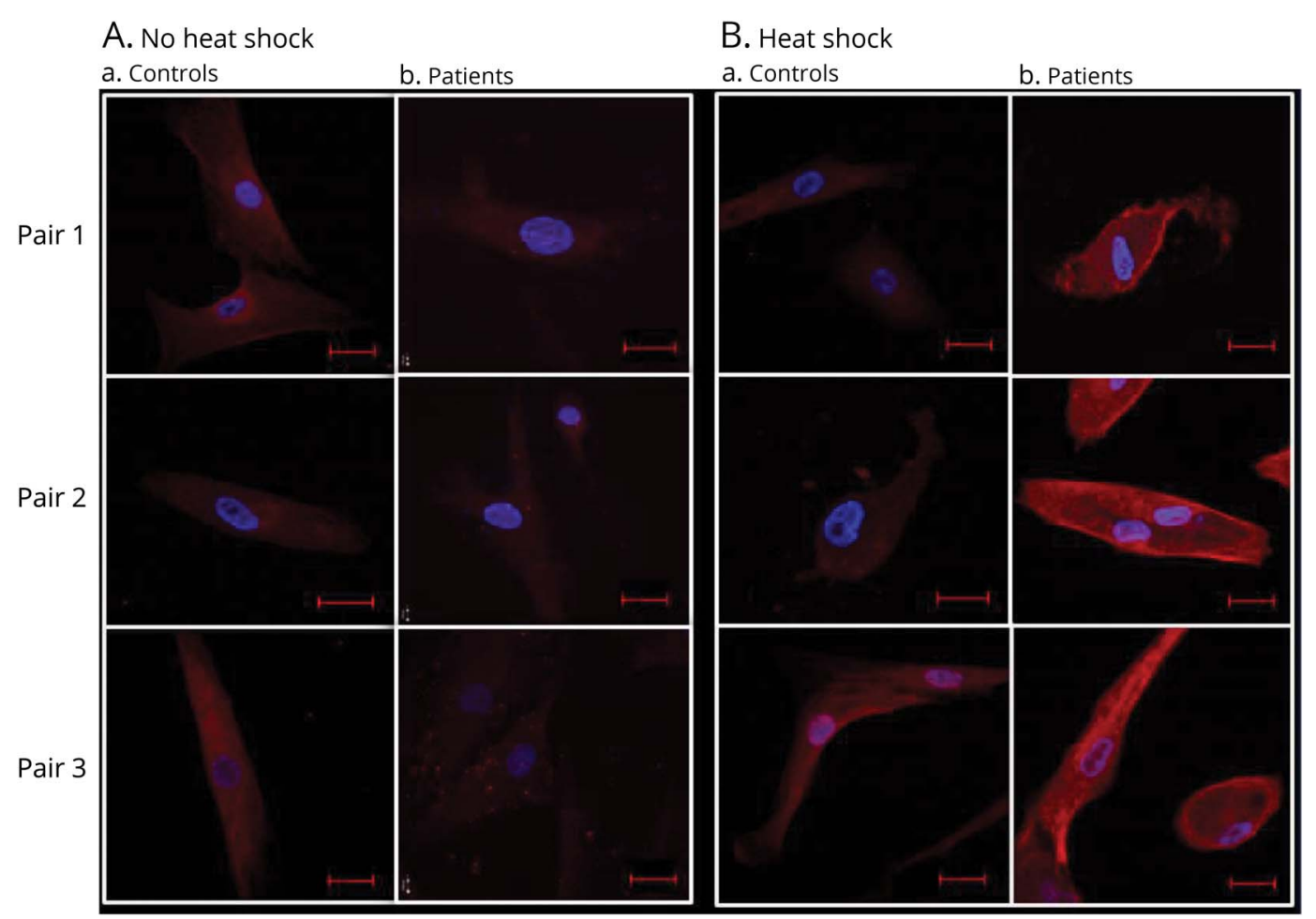

(A) No heat shock condition, (B) heat shock condition. An increase in the amount of HSPB8 protein was present in 3 heated fibroblasts from patients (B1) compared with nonheated fibroblasts (A1). This phenomenon was not observed in control cells (A2 and B2). Pair 1: patient (P1) and control (C1) fibroblasts; pair 2: P2 and C2; pair 3: P3 and C3. 
Table Reported families with HSPB8-related myopathy

\begin{tabular}{|c|c|c|c|c|c|c|c|c|c|c|c|}
\hline Individual & Reference & Mutation & Relationship & Ancestry & Sex & $\begin{array}{l}\text { Age } \\
\text { (y) }\end{array}$ & $\begin{array}{l}\text { Age at } \\
\text { onset }(y)\end{array}$ & CPK (U/L) & $E G^{a}$ & NCS & $\begin{array}{l}\text { RVM } \\
\text { phenotype }\end{array}$ \\
\hline 1 & This study & $\begin{array}{l}\text { c.515dupC, } \\
\text { p.P173SFS*43 }\end{array}$ & Proband & French & M & 44 & 35 & 430 & $+/-$ & Normal & - \\
\hline 2 & & & Mother & & $\mathrm{F}$ & 64 & 56 & 370 & $-1-$ & Normal & + \\
\hline 3 & & & Uncle & & M & 66 & 42 & 327 & $+/+$ & $\begin{array}{l}\text { Motor neuropathy with both axonal and demyelinating } \\
\text { neuroapathy }\end{array}$ & - \\
\hline 4 & 13 & $\begin{array}{l}\text { c. } 421 \mathrm{~A} . \mathrm{G} \\
\text { p.K141E }\end{array}$ & Proband-family I & English & M & 30 & 22 & $850-2,000$ & $+/+$ & $\begin{array}{l}\text { Length-dependent axonal motor neuropathy predominantly } \\
\text { affecting the lower limbs }\end{array}$ & + \\
\hline 5 & & & Mother-family I & & $\mathrm{F}$ & 56 & Childhood & 269 & $+/+$ & Predominantly lower limb axonal motor neuropathy & + \\
\hline 6 & & $\begin{array}{l}\text { c.151insC } \\
\text { p.P173SfsX43 }\end{array}$ & Proband-family II & French & M & 62 & 46 & 369 & $-1+$ & Normal & - \\
\hline 7 & 14 & $\begin{array}{l}\text { c.508_509delCA, } \\
\text { pGln170Glyfs*45 }\end{array}$ & Proband-family A II2 & French & M & 57 & 40 & 449 & $+/-$ & Normal & NA \\
\hline 8 & & & Brother-family A II8 & & M & 55 & 35 & 900 & $+/-$ & & + \\
\hline 9 & & & Daughter, family A III2 & & $\mathrm{F}$ & 45 & 40 & 186 & $+/-$ & & + \\
\hline \multirow[t]{2}{*}{10} & & & Proband, family B III1 & & M & 64 & 40 & 214 & $+/-$ & & NA \\
\hline & & & Proband, family C II1 & & $\mathrm{F}$ & 74 & 40 & 282 & $+/-$ & & NA \\
\hline 12 & 15 & $\begin{array}{l}\text { c. } 421 A>G, \\
\text { p.K141E }\end{array}$ & Proband II1 & Italian & $\mathrm{F}$ & 31 & 20 & 274 & $+/+$ & $\begin{array}{l}\text { Reduced compound motor action potential amplitudes in } \\
\text { lower limbs }\end{array}$ & + \\
\hline 13 & & & Proband sibling II2 & Italian & M & 31 & Early 20s & 656 & $+/+$ & $\begin{array}{l}\text { Absent tibial compound motor action potential bilaterally and } \\
\text { reduced peroneal motor compound action potential } \\
\text { amplitude. Normal conduction velocities. }\end{array}$ & + \\
\hline 14 & & & Proband sibling $\| 3$ & Italian & $\mathrm{F}$ & 31 & Late $20 \mathrm{~s}$ & a & $-1-$ & Normal at 15 years. & - \\
\hline 15 & & & Proband mother 11 & Italian & $\mathrm{F}$ & 58 & 30 & b & $+/+$ & Axonal motor neuropathy & - \\
\hline Mean & & & & & $\begin{array}{l}8 \mathrm{M} / \\
7 \mathrm{~F}\end{array}$ & 51.2 & 33.3 & 517.4 & & $42.8 \%$ abnormal & $\begin{array}{l}47 \% \\
\text { positive }\end{array}$ \\
\hline
\end{tabular}

Abbreviations: CPK = creatinine phosphokinase; NCS = nerve conduction study; RVM = rimmed vacuolar myopathy.

Abbreviation

${ }^{\mathrm{b}}$ Moderately increased CPK. 
pathology in myopathies due to gene defects in other components of the CASA complex such as BAG3 and DNAJB6.

Based on results from animal studies, there has been suggestion of a toxic gain-of-function mechanism for HSPB8 associated $\mathrm{CMT}^{23}$ However, our Western blot densitometry studies exhibited a 50\% reduction of HSPB8 protein expression level in patients compared with control fibroblasts (figure 5). Recently, it was noted ${ }^{14}$ that $\mathrm{N}$-terminal targeting of the protein did not detect this elongated protein suggesting mRNA decay or protein degradation. ${ }^{24}$ In addition, HSPB8 was decreased by $60 \%$ by Western blot quantification. The consequences of the effects of the mutant protein are difficult to predict based on current knowledge because HSPB8 acts in complexes with other chaperones, especially in muscle tissue. The negative effects on the multiprotein complexes may be explained by a dominant negative effect, but haploinsufficiency cannot be excluded. The clear increase of p62 and LC3 in the patient muscle suggests a harmful effect of the mutant protein rather than rapid degradation of the mutant. To clarify this in more detail, a mutant protein-specific antibody would be required to check for eventual accumulation or degradation of the mutant.

Most reported mutations, including the c.515dupC mutation, have occurred within the $\alpha$-crystallin domain that manifests chaperone activity. ${ }^{25}$ Previous studies have shown greater binding of these HSPB8 mutants to the interacting partner HSPB1. Expression of mutant HSPB8 containing the K141C terminal mutations found in hereditary motor and sensory neuropathies in cultured cells had significantly reduced chaperone activity and increased aggregation compared with wild-type protein. ${ }^{12}$

In stress conditions, like heat shock, small heat shock proteins such as HSPB8 increase in concentration to perform their chaperone activity by binding to misfolded protein and blocking the formation of aggregates. During recovery from heat shock under normal conditions, the transcription factor NF- $\mathrm{B}$ (Nuclear factor kappa-light-chain-enhancer of activated $B$ cells) activates the removal of misfolded or aggregated proteins by governing the expression of HSPB8, thereby increasing cell survival. ${ }^{26}$ Our studies indicate that patient cells could not recover after the heat shock stress and displayed an increased HSPB8 expression, also noted by Irobi et al. ${ }^{27}$

We report a new family with HSPB8-associated autosomal dominant RVM, caused by a c.515dupC frameshift mutation resulting in an elongated protein. The clinical features in these individuals bear similarity with recently reported cases. We note reduced expression of HSPB8 in patient fibroblasts compared with age- and sex-matched control fibroblasts supporting our proposal of haploinsufficiency as the mechanism of disease in this newly described disorder.

\section{Acknowledgment}

The authors thank the family for their participation in the clinical studies and Variantyx Inc. (Framingham, MA) for their help with the genome analysis.

\section{Study funding}

The authors thank the Volo Foundation and the Hereditary Inclusion Body Myopathy Foundation for funding this project.

\section{Disclosure}

S. Al-Tahan, L. Weiss, H. Yu, S. Tang, M. Saporta, A. Vihola, T. Mozaffar, B. Udd, and V. Kimonis report no disclosures. Go to Neurology.org/NG for full disclosures.

\section{Publication history}

Received by Neurology: Genetics November 19, 2018. Accepted in final form May 16, 2019.

\begin{tabular}{|c|c|c|c|}
\hline Name & Location & Role & Contribution \\
\hline $\begin{array}{l}\text { Sejad Al- } \\
\text { Tahan, } \\
\text { DO }\end{array}$ & $\begin{array}{l}\text { University of } \\
\text { California, } \\
\text { Irvine, CA }\end{array}$ & Author & $\begin{array}{l}\text { Major role in the acquisition } \\
\text { and analysis of data and } \\
\text { drafted the manuscript for } \\
\text { intellectual } \\
\text { content. }\end{array}$ \\
\hline $\begin{array}{l}\text { Lan } \\
\text { Weiss, } \\
\text { MD, PhD }\end{array}$ & $\begin{array}{l}\text { University of } \\
\text { California, } \\
\text { Irvine, CA }\end{array}$ & Author & $\begin{array}{l}\text { Designed and conceptualized } \\
\text { the study; major role in the } \\
\text { acquisition and interpretation } \\
\text { of data; and drafted the } \\
\text { manuscript for intellectual } \\
\text { content. }\end{array}$ \\
\hline $\begin{array}{l}\text { Howard } \\
\text { Yu, BS }\end{array}$ & $\begin{array}{l}\text { University of } \\
\text { California, } \\
\text { Irvine, CA }\end{array}$ & Author & Acquisition of data. \\
\hline $\begin{array}{l}\text { Sha Tang, } \\
\text { PhD }\end{array}$ & $\begin{array}{l}\text { Ambry } \\
\text { Genetics, } \\
\text { Mission Viejo, } \\
\text { CA }\end{array}$ & Author & $\begin{array}{l}\text { Acquisition and interpretation } \\
\text { of data and revised the } \\
\text { manuscript for intellectual } \\
\text { content. }\end{array}$ \\
\hline $\begin{array}{l}\text { Mario } \\
\text { Saporta, } \\
\text { MD, PhD }\end{array}$ & $\begin{array}{l}\text { University of } \\
\text { Miami, Miami, } \\
\text { FL }\end{array}$ & Author & $\begin{array}{l}\text { Acquisition and interpretation } \\
\text { of data and revised the } \\
\text { manuscript for intellectual } \\
\text { content. }\end{array}$ \\
\hline $\begin{array}{l}\text { Anna } \\
\text { Vihola, } \\
\text { PhD }\end{array}$ & $\begin{array}{l}\text { University of } \\
\text { Helsinki, } \\
\text { Helsinki, } \\
\text { Finland }\end{array}$ & Author & $\begin{array}{l}\text { Acquisition and interpretation } \\
\text { of data and revised the } \\
\text { manuscript for intellectual } \\
\text { content. }\end{array}$ \\
\hline $\begin{array}{l}\text { Tahseen } \\
\text { Mozaffar, } \\
\text { MD }\end{array}$ & $\begin{array}{l}\text { University of } \\
\text { California, } \\
\text { Irvine, CA }\end{array}$ & Author & $\begin{array}{l}\text { Acquisition and interpretation } \\
\text { of data and revised the } \\
\text { manuscript for intellectual } \\
\text { content. }\end{array}$ \\
\hline $\begin{array}{l}\text { Bjarne } \\
\text { Udd, MD, } \\
\text { PhD }\end{array}$ & $\begin{array}{l}\text { University of } \\
\text { Helsinki, } \\
\text { Helsinki, } \\
\text { Finland }\end{array}$ & Author & $\begin{array}{l}\text { Acquisition and interpretation } \\
\text { of data and revised the } \\
\text { manuscript for intellectual } \\
\text { content. }\end{array}$ \\
\hline $\begin{array}{l}\text { Virginia } \\
\text { Kimonis, } \\
\text { MD }\end{array}$ & $\begin{array}{l}\text { University of } \\
\text { California, } \\
\text { Irvine, CA }\end{array}$ & Author & $\begin{array}{l}\text { Designed and conceptualized } \\
\text { the study; major role in the } \\
\text { acquisition and analysis of } \\
\text { data; and drafted the } \\
\text { manuscript for intellectual } \\
\text { content }\end{array}$ \\
\hline
\end{tabular}

\section{References}

1. Arndt V, Dick N, Tawo R, et al. Chaperone-assisted selective autophagy is essential for muscle maintenance. Curr Biol 2010;20:143-148.

2. Fujita $M$, Mitsuhashi $H$, Isogai $S$, et al. Filamin $C$ plays an essential role in the maintenance of the structural integrity of cardiac and skeletal muscles, revealed by the medaka mutant zacro. Dev Biol 2012;361:79-89. 
3. Ehrlicher AJ, Nakamura F, Hartwig JH, Weitz DA, Stossel TP. Mechanical strain in actin networks regulates FilGAP and integrin binding to filamin A. Nature 2011;478: 260-263.

4. Mitra A, Menezes ME, Pannell LK, et al. DNAJB6 chaperones PP2A mediated dephosphorylation of GSK3beta to downregulate beta-catenin transcription target, osteopontin. Oncogene 2012;31:4472-4483.

5. Sarparanta J, Jonson PH, Golzio C, et al. Mutations affecting the cytoplasmic functions of the co-chaperone DNAJB6 cause limb-girdle muscular dystrophy. Nat Genet 2012;44:450-455

6. Kostera-Pruszczyk A, Suszek M, Ploski R, et al. BAG3-related myopathy, polyneuropathy and cardiomyopathy with long QT syndrome. J Muscle Res Cell Motil 2015;36:423-432.

7. Selcen D, Muntoni F, Burton BK, et al. Mutation in BAG3 causes severe dominant childhood muscular dystrophy. Ann Neurol 2009;65:83-89.

8. Kley RA, Serdaroglu-Oflazer P, Leber Y, et al. Pathophysiology of protein aggregation and extended phenotyping in filaminopathy. Brain 2012;135:2642-2660.

9. Ferrer I, Olive M. Molecular pathology of myofibrillar myopathies. Expert Rev Mol Med 2008; 10:e25.

10. Tang BS, Zhao GH, Luo W, et al. Small heat-shock protein 22 mutated in autosomal dominant Charcot-Marie-Tooth disease type 2L. Hum Genet 2005;116: $222-224$.

11. Nakhro K, Park JM, Kim YJ, et al. A novel Lys141Thr mutation in small heat shock protein 22 (HSPB8) gene in Charcot-Marie-Tooth disease type 2L. Neuromuscul Disord 2013;23:656-663.

12. Irobi J, Van Impe K, Seeman P, et al. Hot-spot residue in small heat-shock protein 22 causes distal motor neuropathy. Nat Genet 2004;36:597-601.

13. Ghaoui R, Palmio J, Brewer J, et al. Mutations in HSPB8 causing a new phenotype of distal myopathy and motor neuropathy. Neurology 2016;86:391-398.

14. Echaniz-Laguna A, Lornage X, Lannes B, et al. HSPB8 haploinsufficiency causes dominant adult-onset axial and distal myopathy. Acta Neuropathol 2017;134: 163-165.

15. Cortese A, Laura M, Casali C, et al. Altered TDP-43-dependent splicing in HSPB8related distal hereditary motor neuropathy and myofibrillar myopathy. Eur J Neurol 2018;25:154-163.
16. Farwell Hagman $\mathrm{KD}$, Shinde DN, Mroske C, et al. Candidate-gene criteria for clinica reporting: diagnostic exome sequencing identifies altered candidate genes among $8 \%$ of patients with undiagnosed diseases. Genet Med 2017;19:224-235.

17. Llewellyn KJ, Nalbandian A, Weiss LN, et al. Myogenic differentiation of VCP diseaseinduced pluripotent stem cells: a novel platform for drug discovery. PLoS One 2017; 12:e0176919.

18. Rusmini $\mathrm{P}$, Cristofani $\mathrm{R}$, Galbiati $\mathrm{M}$, et al. The role of the heat shock protein B8 (HSPB8) in motoneuron diseases. Front Mol Neurosci 2017;10:176.

19. Crippa V, Cicardi ME, Ramesh N, et al. The chaperone HSPB8 reduces the accumulation of truncated TDP-43 species in cells and protects against TDP-43-mediated toxicity. Hum Mol Genet 2016;25:3908-3924.

20. Crippa V, Sau D, Rusmini P, et al. The small heat shock protein B8 (HspB8) promotes autophagic removal of misfolded proteins involved in amyotrophic lateral sclerosis (ALS). Hum Mol Genet 2010;19:3440-3456.

21. Kwok AS, Phadwal K, Turner BJ, et al. HspB8 mutation causing hereditary distal motor neuropathy impairs lysosomal delivery of autophagosomes. J Neurochem 2011;119:1155-1161.

22. Irobi J, Almeida-Souza L, Asselbergh B, et al. Mutant HSPB8 causes motor neuron specific neurite degeneration. Hum Mol Genet 2010;19:3254-3265.

23. Bouhy D, Juneja M, Katona I, et al. A knock-in/knock-out mouse model of HSPB8associated distal hereditary motor neuropathy and myopathy reveals toxic gain-offunction of mutant Hspb8. Acta Neuropathol 2017;135:131-148.

24. Echaniz-Laguna A, Geuens T, Petiot P, et al. Axonal neuropathies due to mutations in small heat shock proteins: clinical, genetic, and functional insights into novel mutations. Hum Mutat 2017;38:556-568.

25. Carra S, Sivilotti M, Chavez Zobel AT, Lambert H, Landry J. HspB8, a small heat shock protein mutated in human neuromuscular disorders, has in vivo chaperone activity in cultured cells. Hum Mol Genet 2005;14:1659-1669.

26. Nivon M, Fort L, Muller P, et al. NFkappaB is a central regulator of protein quality control in response to protein aggregation stresses via autophagy modulation. $\mathrm{Mo}$ Biol Cell 2016;27:1712-1727.

27. Irobi J, Holmgren A, De Winter V, et al. Mutant HSPB8 causes protein aggregates and a reduced mitochondrial membrane potential in dermal fibroblasts from distal hereditary motor neuropathy patients. Neuromuscul Disord 2012;22:699-711. 


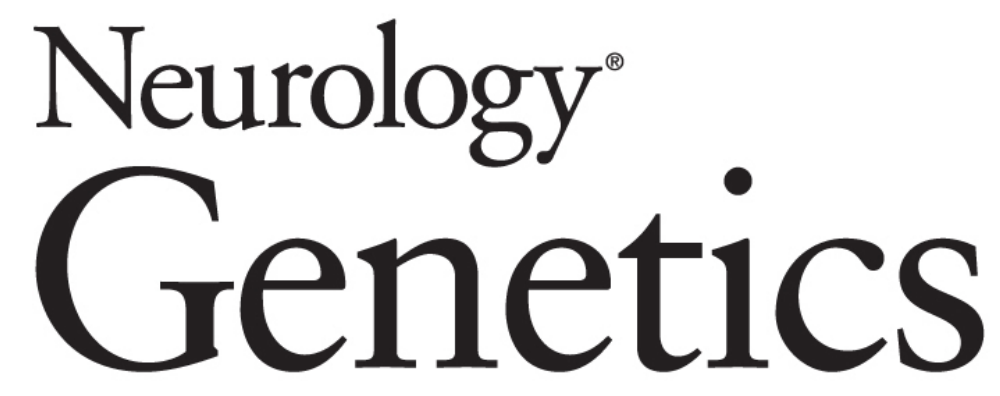

New family with $H S P B 8$-associated autosomal dominant rimmed vacuolar myopathy Sejad Al-Tahan, Lan Weiss, Howard Yu, et al. Neurol Genet 2019;5;

DOI 10.1212/NXG.0000000000000349

This information is current as of July 10, 2019

Updated Information \& Services

References

Subspecialty Collections

Permissions \& Licensing

Reprints including high resolution figures, can be found at: http://ng.neurology.org/content/5/4/e349.full.html

This article cites 27 articles, 1 of which you can access for free at: http://ng.neurology.org/content/5/4/e349.full.html\#\#ref-list-1

This article, along with others on similar topics, appears in the following collection(s):

All Genetics

http://ng.neurology.org//cgi/collection/all_genetics Metabolic disease (inherited)

http://ng.neurology.org//cgi/collection/metabolic_disease_inherited Muscle disease

http://ng.neurology.org//cgi/collection/muscle_disease

Information about reproducing this article in parts (figures,tables) or in its entirety can be found online at:

http://ng.neurology.org/misc/about.xhtml\#permissions

Information about ordering reprints can be found online: http://ng.neurology.org/misc/addir.xhtml\#reprintsus

Neurol Genet is an official journal of the American Academy of Neurology. Published since April 2015, it is an open-access, online-only, continuous publication journal. Copyright Copyright () 2019 The Author(s). Published by Wolters Kluwer Health, Inc. on behalf of the American Academy of Neurology.. All rights reserved. Online ISSN: 2376-7839.

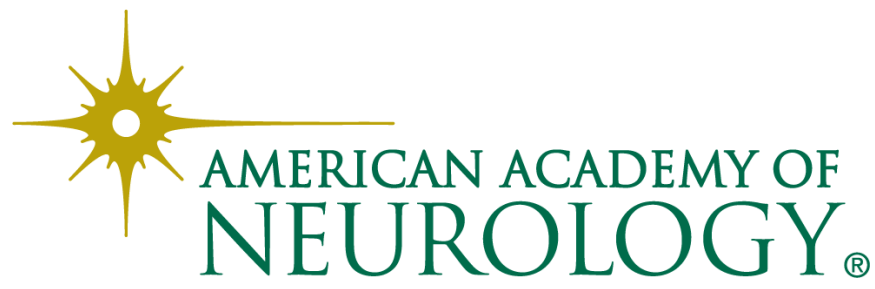

